\title{
Riboflavin-iron interactions with particular emphasis on the gastrointestinal tract
}

\author{
BY HILARY J. POWERS \\ The University Department of Paediatrics, Sheffield Children's Hospital, Sheffield S10 2 TH
}

Riboflavin-responsive anaemia in man was described as early as the 1950 s (Foy \& Kondi, 1953, 1958). The characteristic features included an erythroid hypoplasia and reticulocytopenia. Xanthurenic aciduria, indicative of abnormal tryptophan metabolism, was also reported and suggested that some of the effects of riboflavin deficiency may be secondary to interference with pyridoxine metabolism (Rasmussen et al. 1979). Riboflavin depletion-repletion studies demonstrated that plasma Fe clearance, also, might be impaired in riboflavin deficiency in humans (Lane et al. 1964).

Investigations in rats, pigs, and dogs produced conflicting reports of the effects of riboflavin deficiency on circulating haemoglobin and erythropoiesis (Spector et al. 1943; Endicott et al. 1947; Terrill et al. 1953). Studies of nutritional deficiency anaemias in non-human primates provided further opportunity to characterize the anaemia of riboflavin deficiency and to evaluate the specificity of the haematological and biochemical features (Foy et al. 1964; Foy \& Kondi, 1968).

A more experimental approach by Jamdar et al. (1968) using ${ }^{59} \mathrm{Fe}$ in rats depleted of riboflavin showed a slight decrease in plasma Fe turnover rate compared with pair-fed control animals, which the authors suggested indicated a defect in Fe utilization for haematopoiesis. There was also the suggestion of a reduced lifespan of circulating erythrocytes. Our studies among elderly subjects with poor riboflavin status also suggested a reduction in the lifespan of circulating erythrocytes (Powers \& Thurnham, 1980).

Since riboflavin deficiency appeared to affect haematology without diminishing circulating $\mathrm{Fe}$ concentrations, and in this way differed from simple Fe deficiency, we reasoned that it could act either by reducing the availability of stored or circulating $\mathrm{Fe}$ and/or by diminishing the rate of synthesis of globin or porphyrin. A possible mechanism whereby riboflavin could exert an effect on either of these processes was by reducing the activity of key flavin-dependent enzymes.

\section{FERRITIN-IRON MOBILIZATION}

Ferritin is a predominantly intracellular Fe-storage protein. Fe is retained in the protein shell of ferritin in the oxidized form, $\mathrm{Fe}^{3+}$, and requires reduction in order to be released (Frieden \& Osaki, 1974). Considerable interest has been shown in the likely physiological mechanism whereby ferritin-Fe could be mobilized; various biological reductants, such as ascorbic acid and glutathione, can reduce ferritin-Fe to $\mathrm{Fe}^{2+}$ but at rates that are unlikely to be of any physiological significance. Reduced flavins on the other hand are capable of reducing ferritin-Fe in vitro rapidly and quantitatively (Sirivech et al. 1974). FMN:NADH-linked oxidoreductase activity has been described in cytosolic fractions of cells (Crichton et al. 1975) and a mitochondrial ubiquinone-linked flavin reductase has also been studied (Ulvik, 1983). It was also reported that Fe mobilization from ferritin 
Table 1. Iron metabolism from ferritin in tissue from riboflavin-deficient rats

\begin{tabular}{|c|c|c|c|c|c|}
\hline Reference & System studied & Source of material & $\begin{array}{l}\text { Period of } \\
\text { depletion } \\
\text { (weeks) }\end{array}$ & Controls & $\begin{array}{c}\text { Riboflavin- } \\
\text { deficient } \\
(\% \text { control })^{*}\end{array}$ \\
\hline $\begin{array}{l}\text { Zaman \& Verwilghen } \\
\text { (1977) }\end{array}$ & Liver homogenate & $\begin{array}{l}\text { Young adult } \\
\text { males }\end{array}$ & 24 & Ad lib. & 100 \\
\hline Sirivech et al. (1977) & $\begin{array}{l}\text { Liver homogenate } \\
\text { Kidney homogenate } \\
\text { Duodenal homogenate }\end{array}$ & $\begin{array}{l}\text { Young males } \\
\text { Young males } \\
\text { Young males }\end{array}$ & $\begin{array}{l}8 \\
8 \\
8\end{array}$ & $\begin{array}{l}\text { Ad lib. } \\
\text { Ad lib. } \\
\text { Ad lib. }\end{array}$ & $\begin{array}{l}72 \\
77 \\
44\end{array}$ \\
\hline Powers et al. (1983) & Liver mitochondria & $\begin{array}{l}\text { Lactating dams } \\
\text { Pups }\end{array}$ & $\begin{array}{l}11 \\
\text { Gestation and } \\
3 \text { weeks } \\
\text { suckling }\end{array}$ & $\begin{array}{l}\text { Pair-fed } \\
\text { Pair-fed }\end{array}$ & 62 \\
\hline Powers (1986) & $\begin{array}{l}\text { Duodenal mucosal } \\
\text { homogenate }\end{array}$ & $\begin{array}{l}\text { Young females } \\
\text { Adult females }\end{array}$ & $\begin{array}{l}5 \\
7\end{array}$ & $\begin{array}{l}\text { Weight-matched } \\
\text { Weight-matched }\end{array}$ & $\begin{array}{r}3 \\
23\end{array}$ \\
\hline Powers (1987) & Placental mitochondria & $\begin{array}{l}\text { Pregnant dams: } \\
\text { Day } 18 \\
\text { Day } 21\end{array}$ & $\begin{array}{l}7 \\
7\end{array}$ & $\begin{array}{l}\text { Weight-matched } \\
\text { Weight-matched }\end{array}$ & $\begin{array}{l}70 \\
76\end{array}$ \\
\hline
\end{tabular}

* Calculated from published mean values.

was impaired in some tissue preparations from riboflavin-deficient rats (Sirivech et al. 1977; Zaman \& Verwilghen, 1977), although the absence of appropriate controls, and little information concerning growth rates of the animals, limits interpretation of the data reported (Table 1 ).

The possible importance of riboflavin to ferritin-Fe mobilization in vivo rather depends on the function of ferritin in Fe metabolism. There are a number of potential sites for ferritin involvement in $\mathrm{Fe}$ metabolism including $\mathrm{Fe}$ absorption, hepatic mobilization and haem synthesis.

We investigated the effects of riboflavin deficiency in the rat on ferritin-Fe-mobilizing activity in vitro in a number of different tissue preparations (Table 1). The most profound effect of riboflavin depletion was seen in homogenates prepared from the mucosa of the epithelia of the upper part of the small intestine. After $35 \mathrm{~d}$ of receiving a riboflavin-deficient diet, the rate of $\mathrm{Fe}$ mobilization in mucosal homogenates from riboflavin-deficient animals was only $3 \%$ of that in preparations from weight-matched control animals. A similar effect was observed in adult animals. A strong correlation existed between the rate of $\mathrm{Fe}$ mobilization and riboflavin status measured as the activation coefficient for the flavin-dependent erythrocyte enzyme glutathione reductase (EC 1.6.4.2; Powers, 1986); this was true for both weanling $(r 0.685, P<0 \cdot 001)$ and adult rats $(r 0 \cdot 756, P<0 \cdot 001)$. Hepatic Fe accumulation, which occurs in the normal healthy rat in the neonatal period, was also severely impaired in the young riboflavin-deficient rats; after $35 \mathrm{~d}$ of receiving the riboflavin-depleted diet hepatic ferritin-Fe concentration was only $36 \%$ of that in the livers of control animals (Table 2). These results suggested that FMN-oxidoreductase activity might be involved in $\mathrm{Fe}$ absorption and that riboflavin deficiency, therefore, could impair this process. The failure to accumulate hepatic $\mathrm{Fe}$ neonatally is a consistent characteristic of riboflavin deficiency (Powers, 1985; Adelekan \& Thurnham, 1986a; Powers et al. 1991; Table 2). 
Table 2. Effect of riboflavin deficiency on hepatic iron accumulation in young rats*

\begin{tabular}{|c|c|c|c|c|}
\hline References & Controls & $\begin{array}{c}\text { Period of } \\
\text { depletion } \\
\text { (weeks) }\end{array}$ & $\begin{array}{l}\text { Liver } \mathrm{Fe} \\
\text { concentration } \\
\text { measured as: }\end{array}$ & $\begin{array}{l}\text { Riboflavin- } \\
\text { deficient } \\
\text { (\% control) } \dagger\end{array}$ \\
\hline Sirivech et al. (1977) & Ad lib. & 8 & Total Fe & 60 \\
\hline Powers (1985) & Weight-matched & 7 & $\begin{array}{l}\text { Ferritin-Fe } \\
\text { Non-haem-Fe }\end{array}$ & $\begin{array}{l}44 \\
52\end{array}$ \\
\hline $\begin{array}{l}\text { Adelekan \& Thurnham } \\
\text { (1986a) }\end{array}$ & Weight-matched & 7 & Ferritin-Fe & 73 \\
\hline Powers (1986) & Weight-matched & 5 & Ferritin-Fe & 36 \\
\hline Powers et al. (1991) & Weight-matched & 7 & Total Fe & 92 \\
\hline Powers et al. (1993) & Weight-matched & 5 & Total Fe & 59 \\
\hline
\end{tabular}

* Data are only reported from studies conducted within the first 12 weeks of life of the rats.

$\dagger$ Calculated from published mean values.

An effect of riboflavin deficiency in the rat on the rate of mobilization of $\mathrm{Fe}$ from ferritin was demonstrated also in hepatic mitochondrial preparations from weanling pups (Powers et al. 1983a), and in placental mitochondria prepared from dams late in gestation (Powers, 1987; Table 1). Since FMN was added to the incubation system used for measuring $\mathrm{Fe}$ mobilization, the reduced activity in vitro must have been due to a lower concentration of functional enzyme in the tissues.

Although ferritin is an important intracellular Fe carrier, the nature of its role in $\mathrm{Fe}$ movement between subcellular fractions remains unclear. The importance of riboflavin to ferritin-Fe-mobilizing activity in vitro tells us little of the physiological importance of flavin-dependent $\mathrm{Fe}$ mobilization in vivo. Intervention studies conducted in humans provided further valuable support for the contention that riboflavin deficiency could alter the body's handling of Fe.

\section{HUMAN SUPPLEMENTATION STUDIES}

A few small studies condueted among schoolchildren (Buzina et al. 1979; Charoenlarp et al. 1980) and pregnant women (Decker et al. 1977) had shown that correcting a riboflavin deficiency could improve the haematological response to Fe supplements. We chose to investigate this possibility further in a village population in The Gambia, where biochemical riboflavin deficiency is endemic and there is evidence of poor Fe status among some of the sections of the population (Bates et al. 1981, 1982). Placebocontrolled randomized supplementation studies were carried out among children, adult males, and pregnant and lactating women. Attention was given to the presence of any infection that could influence Fe status. There was biochemical evidence of riboflavin deficiency in virtually all subjects with normal erythrocyte activity for glucose-6phosphate dehydrogenase (EC 1.1.1.49) at the outset of each study (Thurnham, 1972). Haematological response to 6 weeks of Fe supplements alone was variable, particularly among pregnant women. Correcting riboflavin deficiency significantly improved the haematological response to $\mathrm{Fe}$ in the men and the lactating women, and this effect was most evident among men with poor haematological status at the outset (Powers et al. 

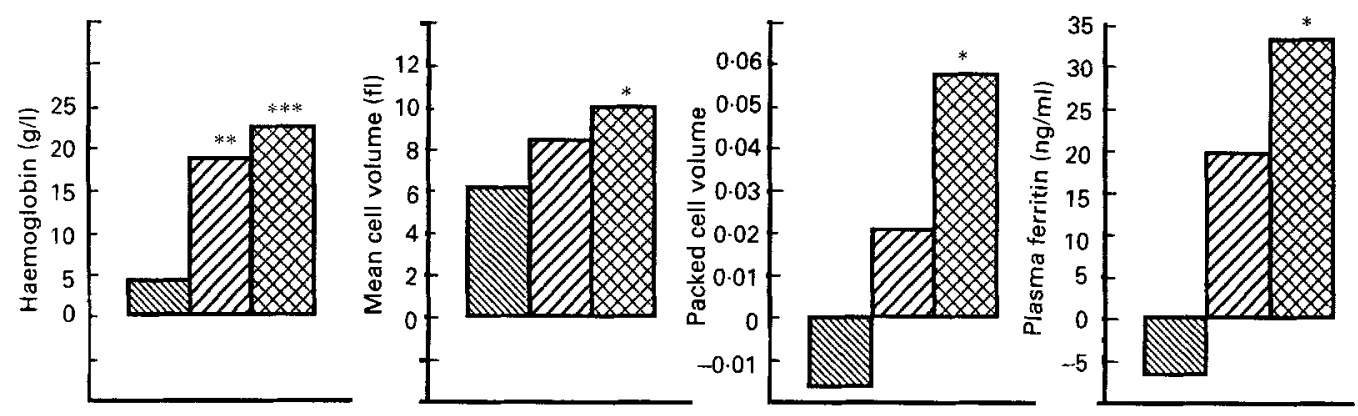

Fig. 1. Effect of correcting a riboflavin deficiency on haematological status in adult males. Values are mean

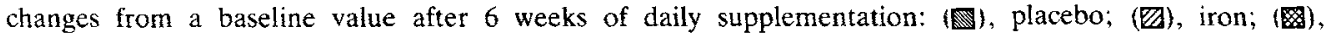
$\mathrm{Fe}+$ riboflavin. Mean values were significantly different from baseline value: ${ }^{*} P<0 \cdot 02,{ }^{* *} P<0 \cdot 01,{ }^{* * *} P<0 \cdot 001$. Based on data from Powers et al. (1983b).

$1983 b, 1985 ;$ Fig. 1). These results suggested that correcting a riboflavin deficiency improved the supply of Fe to the erythroid marrow. The Fe could come from Fe stores or directly from the diet.

In order to clarify the mechanism whereby riboflavin influences Fe metabolism in man we investigated the effects of riboflavin deficiency in rats on Fe absorption.

\section{EFFECTS IN THE GASTROINTESTINAL TRACT}

Fe absorption was measured in young female rats fed on a riboflavin-deficient diet for 7 weeks and compared with absorption in weight-matched control animals (Powers et al. 1988). A test meal extrinsically labelled with ${ }^{59} \mathrm{Fe}$ was fed to all animals and the whole-body radioactivity measured in a small-animal gamma counter (NE 8112; Nuclear Enterprises, Edinburgh) daily for $15 \mathrm{~d}$. We took care to standardize Fe intakes over $3 \mathrm{~d}$ before the feeding of the test meal, a factor which would have influenced results (Fairweather-Tait et al. 1985). The percentage of the dose absorbed at the time of the test meal was calculated from an extrapolated plot of percentage dose retained over the $15 \mathrm{~d}$ after the test meal. There was a $15 \%$ reduction in the dose absorbed by the riboflavin-deficient animals when compared with that of the controls (Fig. 2). Unexpectedly, riboflavin deficiency was associated also with a substantial increase in the rate of loss of ${ }^{59} \mathrm{Fe}$, post-absorption. At this time Adelekan \& Thurnham (1986b) reported that riboflavin deficiency in the young rat was associated with a delay and a reduction in the appearance in the plasma of a gastric dose of ${ }^{59} \mathrm{Fe}$. It is unclear whether differences in dietary Fe before the test dose could have influenced results but these findings supported our view that riboflavin deficiency impairs the absorption of $\mathrm{Fe}$. We subsequently confirmed that riboflavin deficiency induced in the young rat leads to an impaired absorption of $\mathrm{Fe}$ and increases the rate of $\mathrm{Fe}$ loss (Powers et al. 1991). All the post-absorption Fe loss was faecal, confirming that the loss was gastrointestinal. A recent report of reduced uptake of $\mathrm{Fe}$ by brush-border-membrane vesicles from riboflavindeficient rats is compatible with a reduced Fe absorption (Butler \& Topham, 1993).

We were unable to demonstrate that correcting a riboflavin deficiency in adult males improved $\mathrm{Fe}$ absorption when measured by neutron-activation analysis using the stable 

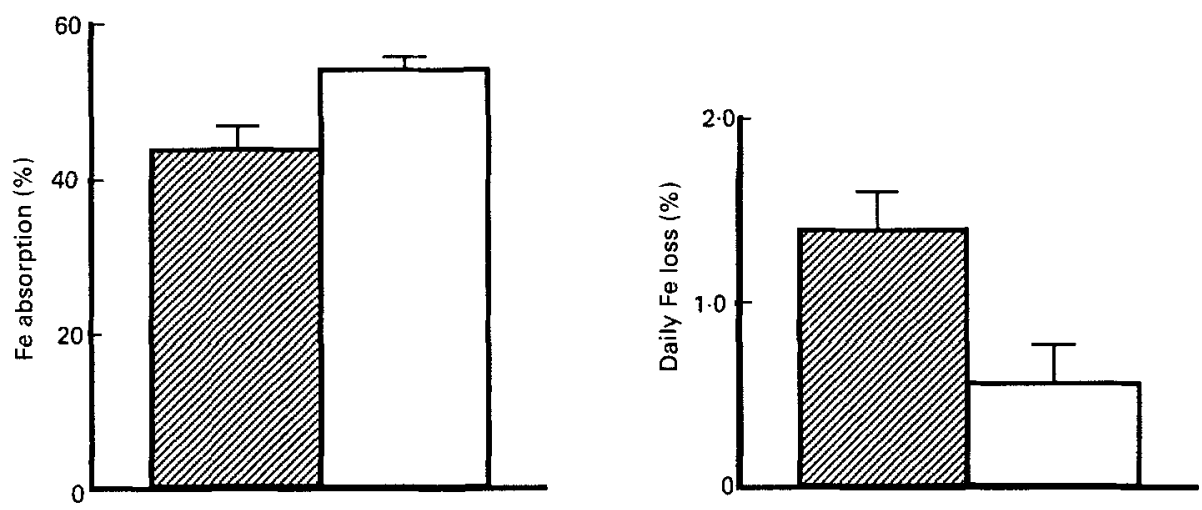

Fig. 2. Effects of riboflavin deficiency in weanling rats on the absorption and the daily post-absorption loss of iron following a test meal extrinsically labelled with ${ }^{59} \mathrm{Fe}$. ( $\square$ ), Weight-matched controls; (ש্ ), riboflavindeficient. Values are mean with their standard errors represented by vertical bars.

isotope ${ }^{58} \mathrm{Fe}$ (Fairweather-Tait et al. 1992). However, there was a very large variability in Fe absorption between subjects and we believe that the method used was insufficiently sensitive to detect small improvements in Fe absorption. This study did show, however, that improving riboflavin status elicited a significant increase in the concentration of circulating haemoglobin. Whether this reflects an increase in Fe absorption after all or an increased efficiency of utilization of Fe for haem synthesis is not yet known.

Our attention has subsequently focused on the intestinal mechanisms whereby riboflavin exerts an effect on Fe absorption and gastrointestinal loss. We suggested that the enhanced rate of endogenous Fe loss seen in riboflavin deficiency was caused by an increase in the rate of turnover of epithelial cells of the small intestine. An exploratory experiment was carried out in young rats in which we estimated the number of cells in mitosis per crypt in the upper part of the small intestine, following intraperitoneal injection with the metaphase arrest agent, vincristine. This method of measuring crypt cell proliferation has been well-validated (Wright \& Appleton, 1980; Wright \& Irwin, 1982). Riboflavin deficiency in young rats resulted in a doubling of the mitotic index. This apparent increase in proliferative response was characterized also by an increase in crypt depth and width in the duodenum (Table 3). These observations encouraged us to look more closely at the cytokinetics of the duodenum. In order to confirm that an increased mitotic index actually reflected an increased rate of production of cells in the crypts of the small intestine we adopted the stathmokinetic method to measure crypt cell production rate (CCPR). Young rats received an intraperitoneal injection of vincristine and were killed by cervical dislocation at fixed time-points up to 90 min after the injection. The small intestine was removed from each animal and segments stained for nuclear material. The number of cells in metaphase arrest per crypt was measured after microdissection. CCPR was calculated as the slope of the regression of metaphase arrest values $v$. time after injection. Riboflavin deficiency was associated with a doubling of the CCPR in the upper and small intestine compared with weight-matched and ad lib.-fed control animals (Powers et al. 1993; Table 3).

More recently these studies have been developed to include villi morphometry and the kinetics of cell movement on the villi. Female Wistar rats were weaned onto a diet 
Table 3. Morphological and cytokinetic characteristics of the small intestine in riboflavin deficiency $\dagger$

(Mean values with their standard errors)

\begin{tabular}{|c|c|c|c|c|c|c|}
\hline \multirow[b]{2}{*}{ Variable } & \multicolumn{2}{|c|}{ Riboflavin-deficient } & \multicolumn{2}{|c|}{$\begin{array}{l}\text { Weight-matched } \\
\text { controls }\end{array}$} & \multicolumn{2}{|c|}{ Ad lib.-fed controls } \\
\hline & Mean & SEM & Mean & SEM & Mean & SEM \\
\hline Villus length $(\mu \mathrm{m})$ & $622 *$ & 25 & 532 & 21 & 549 & 42 \\
\hline No. of cells per villus & $111^{* *}$ & $3 \cdot 0$ & 99 & $2 \cdot 1$ & 99 & 3.8 \\
\hline Crypt depth $(\mu \mathrm{m})$ & $253^{* * *}$ & 6.4 & 196 & $6 \cdot 0$ & 188 & $9 \cdot 1$ \\
\hline Crypt width $(\mu \mathrm{m})$ & $63^{* *}$ & $32 \cdot 1$ & 55 & $2 \cdot 2$ & 59 & $2 \cdot 3$ \\
\hline \multicolumn{7}{|l|}{ Crypt cell production rate } \\
\hline (/ten crypts per $h)$ & $20 * * *$ & $2 \cdot 3$ & 11 & $2 \cdot 8$ & 8 & 0.7 \\
\hline Enterocyte transit rate $(\mu \mathrm{m} / \mathrm{h})$ & $7 \cdot 2^{* * *}$ & 0.54 & 3.5 & $0 \cdot 25$ & & \\
\hline \multicolumn{7}{|l|}{ Villus no. (per $10 \mathrm{~mm}$} \\
\hline length duodenum) & $1335 * *$ & 115 & 1780 & 88 & & \\
\hline
\end{tabular}

Mean values were significantly different from those of controls: $* P<0 \cdot 05,{ }^{* *} P<0 \cdot 01,{ }^{* * *} P<0 \cdot 001$.

$\uparrow$ Based on data from Powers et al. (1993) and Williams et al. (1994a,b, 1995).

deficient in riboflavin; after receiving this diet for 5 weeks they were compared with weight-matched and $a d$ lib.-fed controls that had received a complete diet. Sections of the duodenum were cut and stained for the measurement of villus height, and enterocyte number on the villi, using light microscopy. The villi from the riboflavin-depleted animals were longer and had a greater number of enterocytes per villus column than either control group (Williams et al. 1995; Table 3). Despite the increase in villus height and cellularity in riboflavin deficiency the total DNA content of the small intestine was not influenced, suggesting that riboflavin deficiency may interfere with the usual increase in the number of villi during post-weaning development. We have confirmed very recently that riboflavin deficiency induced at weaning does impair the increase in villus number that we observe over 5 weeks post-weaning in weight-matched controls (Williams et al. 1994a; Table 3). An increase in villus height may be a mechanism whereby a riboflavin-deficient animal attempts to compensate for a reduction in villus number and thereby maintain the absorptive surface area of the small intestine. Studies of the time-scale for these changes during riboflavin depletion are helping to clarify this.

The net absorptive efficiency of the surface of the small intestine will be determined by the number of functionally mature enterocytes on the villi. These cells are produced from stem cells in the crypts, differentiate as they progress towards the villus, and mature as they move along the villus. Functional maturity of enterocytes is conventionally expressed as the activity of certain enzymes with absorptive function, in particular, disaccharidases and alkaline phosphatase (EC 3.1.3.1; King et al. 1983). It is unclear how such activity relates to the absorption of Fe and whether, therefore, the capacity of an enterocyte for $\mathrm{Fe}$ absorption changes in the same manner as the cell moves along the villus. What one would predict, whatever the mechanism for Fe absorption, is that the shorter the time an enterocyte remains on a villus the shorter its absorptive life. We have studied whether riboflavin deficiency influences the rate of transit of enterocytes onto and along the villi using a technique which labels cells as they are produced in the crypts, for later identification on the villi. 
The method adopted to measure the rate of transit of cells along villi uses bromodeoxyuridine (Budr), a thymidine analogue, which is incorporated into DNA during the ' $S$ ' phase of cell division (Wynford-Thomas \& Williams, 1986). After intraperitoneal injection Budr is taken up by proliferating cells, including those in the crypts of the small intestine. The time that elapses between the injection and placing tissue in fixative will determine the location of the labelled cells on the villi. The Budr can be detected in histological sections of the tissue using a monoclonal-antibody technique. We have demonstrated an increased rate of transit of cells from the crypts and along the villi of the small intestine in weanling riboflavin-deficient rats compared with weightmatched controls (Williams et al. 1994b; Table 3). Despite an increased villus length in riboflavin deficiency, the leading edge of the cohort of labelled cells had covered a greater percentage of the villi than in the control animals. If, as these results suggest, riboflavin deficiency leads to enterocytes spending a shorter time on the villi, we would predict that the absorptive capacity of the villi is reduced. This may be a factor determining the effect of riboflavin deficiency on $\mathrm{Fe}$ absorption. The mechanism for the regulation of Fe absorption in the small intestine is still not fully understood, but may include a role for newly identified Fe-binding proteins integrin and mobilferrin, at the surface of, and in the cytosol of, enterocytes (Conrad et al. 1993). The concentration of these Fe-binding proteins and the number of Fe-binding sites they display may regulate the transfer of Fe from the lumen to the blood plasma and may be influenced by the lifespan of the enterocyte on the villus surface. Also, an enhanced rate of loss of endogenous $\mathrm{Fe}$ would be predicted.

Studies are currently in progress to determine the reversibility of the morphometric and cytokinetic changes observed when riboflavin deficiency is induced at or before weaning. The neonatal period is one of structural and functional maturation of the small intestine and riboflavin deficiency during this period may have long-term consequences. It is unlikely that $\mathrm{Fe}$ is the only nutrient whose metabolism is influenced by the profound morphometric and cytokinetic changes seen in the small intestine in riboflavin deficiency.

The mechanism whereby riboflavin exerts its effect on cell proliferation is not yet known. We are planning to extend our studies to the use of tissue-culture techniques to address this question.

\section{CONCLUSIONS}

Riboflavin deficiency alters the body's normal handling of Fe. It impairs absorption and increases the rate of gastrointestinal loss of endogenous Fe. It may also reduce the efficiency of Fe utilization for haem synthesis. The effects on absorption and gastrointestinal loss appear to result from a hyperproliferation of crypt cells and an increased rate of transit of enterocytes along the villi, probably leading to functionally immature villi. A failure to increase villus number in the small intestine observed post-weaning in riboflavin deficiency would predictably reduce the absorptive surface area and contribute to the effect on Fe absorption. An increase in villus length may be an adaptation to the observed failure to increase villus number. The effects of changes in the small intestine are unlikely to be specific to Fe.

All studies involving human subjects were carried out with the approval of the University of Cambridge Ethics Committee. The studies described here were carried out with the collaboration of many colleagues whose assistance the author gratefully acknowledges. 
Financial support was provided by The Medical Research Council, Hoffmann-La Roche Ltd, and The Wellcome Trust.

\section{REFERENCES}

Adelekan, D. A. \& Thurnham, D. I. (1986a). Effects of combined riboflavin and iron deficiency on the haematological status and tissue iron concentrations of the rat. Journal of Nutrition 116, 1257-1265.

Adelekan, D. A. \& Thurnham, D. I. $(1986 \mathrm{~b})$. The influence of riboflavin deficiency on absorption and liver storage of iron in the growing rat. British Journal of Nutrition 56, 171-179.

Bates, C. J., Prentice, A. M., Paul, A. A., Prentice, A., Sutcliffe, B. A. \& Whitehead, R. G. (1982). Riboflavin status in infants born in rural Gambia, and the effect of a weaning food supplement. Transactions of the Royal Society of Tropical Medicine and Hygiene 76, 253-258.

Bates, C. J., Prentice, A. M., Paul, A. A., Sutcliffe, B. A., Watkinson, M. \& Whitehead, R. (1981). Riboflavin status in Gambian pregnant and lactating women and its implications for recommended dietary aliowances. American Journal of Clinical Nutrition 34, 928-935.

Butler, B. F. \& Topham, R. W. (1993). Comparison of changes in the uptake and mucosal processing of iron in riboflavin-deficient rats. Biochemistry and Molecular Biology International 30, 53-61.

Buzina, R., Jusic, M., Milanovic, N., Sapunar, J. \& Brubacher, G. (1979). The effects of riboflavin administration on iron metabolism parameters in a school-going population. International Journal for Vitamin and Nutrition Research 49, 136-143.

Charoenlarp, P., Pholphothi, T., Chatpunyaporn, P. \& Schelp, F. P. (1980). The effect of riboflavin on the hematologic changes in iron supplementation of schoolchildren. Southeast Asian Journal of Tropical Medicine and Public Health 11, 97-103.

Conrad, M. E., Unmreit, J. N. \& Moore, E. G. (1993). Regulation of iron absorption: proteins involved in duodenal mucosal uptake and iron transport. Journal of the American College of Nutrition 12, 720-728.

Crichton, R. R., Roman, F. \& Wauters, M. (1975). Reductive mobilisation of ferritin iron by reduced nicotinamide adenine dinucleotide via flavin mononucleotide. Biochemical Society Transactions 3, 946-948.

Decker, K., Dotis, B., Glatzle, D. \& Hinselmann, M. (1977). Riboflavin status and anaemia in pregnant women. Nutrition and Metabolism 21, Suppl. 1, 17-19.

Endicott, K. M., Kornberg, A. \& Ott, M. (1947). Hemopoiesis in riboflavin-deficient rats. Blood 2, $164-174$.

Fairweather-Tait, S. J., Powers, H. J., Minski, M. J., Whitehead, J. \& Downes, R. (1992). Riboflavin deficiency and iron absorption in adult Gambian men. Annals of Nutrition and Metabolism 36, 34-40.

Fairweather-Tait, S. J., Swindell, T. E. \& Wright, A. J. A. (1985). Further studies in rats of the influence of previous iron intake on the estimation of the bioavailability of Fe. British Journal of Nutrition 54, 79-86.

Foy, H. \& Kondi, A. (1953). A case of true red-cell aplastic anaemia successfully treated with riboflavin. Journal of Pathological Bacteriology 65, 559-564.

Foy, H. \& Kondi, A. (1958). Anemias of the Tropics: East Africa, with special reference to proteins and liver damage. Transactions of the Royal Society of Tropical Medicine and Hygiene 52, 46-70.

Foy, H. \& Kondi, A. (1968). A comparison between erythroid aplasia in marasmus and kwashiorkor and the experimentally induced erythroid aplasia in baboons by riboflavin deficiency. Vitamins and Hormones 26, 653-679.

Foy, H., Kondi, A. \& Mbaya, V. (1964). Effect of riboflavin deficiency on bone marrow function and protein metabolism in baboons. Preliminary report. British Journal of Nutrition 18, 307-317.

Frieden, E. \& Osaki, S. (1974). Ferroxidases and ferrireductases: their role in iron metabolism. Advances in Experimental Biology and Medicine 48, 235-265.

Jamdar, S. C., Udupar, K. B. \& Chatterji, A. (1968). Study of hematopoiesis in riboflavin deficient rats with ${ }^{59} \mathrm{Fe}$ as tracer. Journal of Nutritional Science and Vitaminology 14, $219-222$.

King, I. S., Paterson, Y. J. F., Peacock, M. A., Smith, M. W. \& Syme, G. (1983). Effect of diet on enterocyte differentiation in the rat jejunum. Journal of Physiology 344, 465-481.

Lane, M., Alfrey, C. P., Mengel, C. E., Doherty, M. N. A. \& Doherty, J. (1964). The rapid induction of human riboflavin deficiency with galactoflavin. Journal of Clinical Investigation 43, 357-373.

Powers, H. J. (1985). Experiment to determine the effect of riboflavin deficiency at weaning on iron economy and heme synthesis. Annals of Nutrition and Metabolism 29, 261-266.

Powers, H. J. (1986). Investigation into the relative effects of riboflavin deficiency on iron economy in the weanling rat and the adult. Annals of Nutrition and Metabolism 30, 308-315.

Powers, H. J. (1987). A study of maternofetal iron transfer in the riboflavin deficient rat. Journal of Nurrition 117, 852-856. 
Powers, H. J., Bates, C. J. \& Duerden, J. M. (1983a). Effects of riboflavin deficiency in rats on some aspects of iron metabolism. International Journal for Vitamin and Nutrition Research 53, 371-376.

Powers, H. J., Bates, C. J. \& Lamb, W. H. (1985). Haematological response to supplements of iron and riboflavin to pregnant and lactating women in rural Gambia. Human Nutrition: Clinical Nutrition 39C, $117-129$.

Powers, H. J., Bates, C. J., Prentice, A. M., Lamb, W. H., Jepson, M. \& Bowman, H. (1983b). The relative effectiveness of iron and iron with riboflavin in correcting a microcytic anaemia in men and children in rural Gambia. Human Nutrition: Clinical Nutrition 37C, 413-425.

Powers, H. J. \& Thurnham, D. I. (1980). Physiological effects of marginal riboflavin deficiency in young adults and geriatrics: a reduction in the survival time of erythrocytes. Proceedings of the Nutrition Society 39, 17A.

Powers, H. J., Weaver, L. T., Austin, S. \& Beresford, J. K. (1993). A proposed intestinal mechanism for the effect of riboflavin deficiency on iron loss in the rat. British Journal of Nutrition 69, 553-561.

Powers, H. J., Weaver, L. T., Austin, S., Wright, A. J. A. \& Fairweather-Tait, J. (1991). Riboflavin deficiency in the rat: effects on iron utilisation and loss. British Journal of Nutrition 65, 487-496.

Powers, H. J., Wright, A. J. A. \& Fairweather-Tait, S. J. (1988). The effect of ribofiavin deficiency in rats on the absorption and distribution of iron. British Journal of Nutrition 59, 381-387.

Rasmussen, K. N., Barsa, P. M. \& McCormick, D. B. (1979). Pyridoxamine (Pyridoxine) 5'phosphate oxidase activity in rat tissues during development of riboflavin or pyridoxine deficiency. Proceedings of the Society for Experimental Biology and Medicine 161, 527-530.

Sirivech, S., Driskell, J. \& Frieden, E. (1977). NADH-FMN oxidoreductase activity and iron content of organs from riboflavin-deficient and iron-deficient rats. Journal of Nutrition 107, 739-745.

Sirivech, S., Frieden, E. \& Osaki, S. (1974). The release of iron from horse spleen ferritin by reduced flavins. Biochemical Journal 143, 311-315.

Spector, H., Mass, A. R., Michaud, L., Elverjem, C. A. \& Hart, E. B. (1943). The role of riboflavin in blood regeneration. Journal of Biological Chemistry 150, 75-87.

Terrill, S. W., Ammerman, C. B., Walker, D. E., Edwards, R. M., Norton, H. W. \& Becker, D. E. (1953). Riboflavin studies in pigs. Journal of Animal Science 14, 593-601.

Thurnham, D. I. (1972). Influence of glucose-6-phosphate dehydrogenase deficiency on the glutathione reductase test for ariboflavinosis. Annals of Tropical Medicine and Parasitology 66, 505-507.

Ulvik, R. J. (1983). Reduction of exogenous flavins and mobilisation of iron from ferritin by isolated mitochondria. Journal of Bioenergetics and Biomembranes 15, 151-160.

Williams, E. A., Powers, H. J. \& Rumsey, R. D. E. (1994a). Riboflavin depletion at weaning is associated with a failure to reach normal villus number in the rat duodenum. Proceedings of the Nutrition Society 53, $209 \mathrm{~A}$.

Williams, E. A., Powers, H. J. \& Rumsey, R. D. E. (1995). Morphological changes in the rat small intestine in response to riboflavin depletion. British Journal of Nutrition 73, 141-146.

Williams, E. A., Rumsey, R. D. E. \& Powers, H. J. (1994b). Riboflavin depletion enhances the transit of enterocytes along the villi. Proceedings of the Nutrition Society 53, 149A.

Wright, N. A. \& Appleton, D. R. (1980). The metaphase arrest technique: a critical review. Cell Tissue Kinetics 13, 643-663.

Wright, N. A. \& Irwin, M. (1982). The kinetics of villus cell populations in the mouse small intestine. Cell Tissue Kinetics 15, 596-609.

Wynford-Thomas, D. \& Williams, E. D. (1986). Use of bromodeoxyuridine for cell kinetic studies in intact animals. Cell Tissue Kinetics 19, 179-182.

Zaman, Z. \& Verwilghen, R. L. (1977). Effect of riboflavin deficiency on activity of NADH-FMN oxidoreductase (ferriductase) and iron content of rat liver. Biochemical Society Transactions 5, 306-308. 